\title{
Nutritive potential of some 'edible' soils in Blantyre city, Malawi
}

\section{D Lakudzala and J J Khonje}

Department of Physics and Biochemistry, Polytechnic, University of Malawi

Corresponding Author: D. D. Lakudzala dlakudzala@poly.ac.mw Abstract

\section{Background}

Pregnant women in Malawi consume soil, but the nutritive potential of these soils is uncertain.

\section{Methods}

We collected 'edible' Malawian soil samples from Ndirande, Mpingwe and Soche hills and bought an Indian soil sample from a shop in Limbe and tested them for iron, calcium, zinc, magnesium, lead, $\mathrm{pH}$, Bacillus and Clostridium, using standard methods of analyses.

\section{Findings}

Based on an average daily consumption of fifty grammes of soil, Blantyre 'edible' soils can supply $0.006 \%, 0.2 \%, 7 \%$ and $74 \%$ whilst the Indian soil may supply $0.008 \%, 0.27 \%, 8.7 \%$, and $65 \%$ of the WHO recommended minimum daily intakes of Magnesium, Calcium, Zinc and iron, respectively. However, both the Blantyre and Indian 'edible' soils also have some traces of lead ( 0.05 to $0.07 \mathrm{mg} / \mathrm{g}$ soil) and spores of Bacillus (4900 - 13475 colonies/gram) and Clostridium (5050 - 9050 colonies/gram), which may have undesirable health effects.

Blantyre soils were similar but significantly different from the Indian soil which had higher calcium, magnesium, zinc and lead but lower iron.

\section{Conclusion}

The soils have nutritive potential, but they also have harmful aspects.

\section{Recommendation}

Further multidisciplinary research should be conducted to assess the nutritive potential of soils from other areas in Malawi and to examine the health effects of lead and bacterial spores.

\section{Introduction}

Human beings inadvertently eat a little soil through soil contaminated food, soiled hands and inhaled dust. This soil can pose a health threat, especially near sites of industrial contamination, but soil eaten intentionally poses a greater challenge ${ }^{1}$. Reasons for intentional eating of soil include pica (the eating of non - food items due to unusual appetite), cultural tradition, health and religion ${ }^{2}$. Traditionally and culturally people used clays in food preparation. Clays were used by native Americans in California, Peru and Sardinia (Italy), who would eat clay with acorn and potatoes or use clay to prepare acorn bread to neutralise toxins such as alkaloids in acorn; as condiments or spices (for example in the Philippines, New Guinea, Costa Rica, Guatemala, the Amazon and Orinoco basins of south America), and as food during famine ${ }^{3}$. Clays have been used in medication (for example kaolin clay in kaopectate) and in prevention of nausea in pregnant women; religious tradition (for example, people from all over the world go to the Catholic shrine in Esquipalas in Guatemala and to El Santuario de Chimayo in the hills of northern New Mexico to eat the deep red soil of Chimayo) $)^{4}$. But the most common occasion for eating soil in many societies is pregnancy. Soil eating (geophagy) is common in pregnant women in Africa and migrants to Africa ${ }^{1,5}$. However, geophagy is not always confined to pregnant women. It is practised by members of all races, social classes, ages and sexes in some parts of the world 5 .
Children also eat soils. Past research on causes of pica in children suggest that the disease is an appetite which is caused by mineral deficiency such as iron deficiency ${ }^{6}$. Often the substance eaten by someone with pica contains the mineral in which that individual is deficient.

The timing of soil ingestion and amounts consumed vary with tribes and individual persons. The amounts of soil consumed, worldwide, range from 30 to 60 grammes of soil per day ${ }^{1}$. In sub-Saharan Africa, soils eaten are sub-surface (60 $90 \mathrm{~cm}$ ) clays, kaolin and montmorillonite ${ }^{7}$. Traders make rural clays available for geophagy for urban settings. Clays from termite mounds are especially popular among traded clays, perhaps because of their flavour and taste. Incidentally these soils are rich in calcium ${ }^{7}$. In some cultures clays are baked before they are eaten. Children world wide, usually less than two years old, ingest considerable amounts of soil ${ }^{7}$. The Environmental Protection Agency (EPA) estimates that in the U.S. children consume on average, $200800 \mathrm{mg}$ soil per day. Children consume top soils and are less selective about the sites they choose for soil to eat ${ }^{7}$.

\section{Advantages of eating soils}

Clays may relieve gastric distress but top soils are not as effective as deep soils at gastric soothing ${ }^{4}$. Wiley and Katz have proposed that eating clay serves different purposes during different periods of pregnancy, soothing stomach upset during morning sickness in the first trimester and supplementing nutrients (especially $\mathrm{Ca}$ ) during the second trimester, when the foetal skeleton is forming ${ }^{7}$ ). Soils eliminate nausea possibly because the clay coats the gastro intestinal tract and may absorb dangerous toxins. Paraquat poisoning victims were told to promptly swallow soil because it is deactivated upon contact with soil ${ }^{2}$.

Since monkeys that regularly eat soil have lower parasite loads 8 . It is postulated that regular consumption of soil by pregnant women might boost the women's secretory immune system. Gut - associated lymphoid tissue is a major site of intense immunologic activity in children and adults. Although it is not clear why antigens introduced in the gut either promote tolerance of microorganisms or immunize against them, it is clear that immunization through the gut is a major source of immunoglobulin $(\operatorname{IgA})^{9}$. Aluminium salts have been used for sometime as adjuvants (amplifiers of immune response) in human vaccines. For this reason it is believed that aluminium compounds which are contained in soil clay make immunologic adjuvants ${ }^{4}$. The clays might act as vaccines, stimulating the production of antibodies $(\operatorname{IgA})$ against organic antigens such as parasites. The antibodies occur in breast milk and have a major role in mucosal protection of newborns. The IgA is found in the breast milk shortly before birth, and provides protection for infants against the pathogens encountered immediately after birth ${ }^{4}$. Furthermore, IgA antibodies prevent attachment of bacteria and some viruses at mucosal surfaces ${ }^{10}$, the major contact between the infant and the infectious world. In summary eating soil is thought to enhance foetal immunity, increase calcium supply, eliminate gastric upset, detoxify some plant and animal toxins, and possibly boost mother's immunity.

\section{Risks of eating soils}

Soil is a "biologic sink". It contains nutrients, toxic elements, 
organic matter and microbes among other things. The soil can pose a health threat. It was postulated by Ellis and Schnoes in 2002 that people who eat soil risk psychological abnormalities and health consequences such as lead poisoning and bacterial or parasitic or worm infection. Most spore forming bacteria, such as bacillus and clostridium, like to live in soils ${ }^{11}$. A person can start feeling some abdominal pains when the soil or food contains about 105 colonies of bacillus or clostridium per gram of soil or food in the body ${ }^{12}$.

Clostridium in the female genital tract may induce abortion and result in uterine gas gangrene ${ }^{12}$.

The Centre for Disease Control and Prevention (CDCP) in California reported that two children who ate soils were infected with racoon roundworm (Baylisascaris procyonis) and had severe neurological damage which resulted in the death of one of the children ${ }^{13}$. In the U.S., the most common parasitic infection associated with geophagy is toxocariasis with the most common route of infection being through ingestion of soil contaminated with dog or cat faeces ${ }^{14}$. Geissler reported correlation between geophagy and ascariasis, which is caused by, Ascaris Lumbricoides ${ }^{15}$. Among children in Nigeria, the most common parasitic infection associated with geophagy is ascariasis, and this sometimes caused intestinal obstruction ${ }^{16}$. Geophagy is also a risk factor for geo-helminth infection ${ }^{17}$.

However it should be noted that not all who eat soil routinely contract disease. There are few reports of infections routinely associated with geophagy by pregnant women in sub-Saharan Africa, probably because women dig clays from $60-90 \mathrm{~cm}$ below the soil surface, and sometimes they bake the clays. It could also be due to inadequate research or epidemiological surveys.

\section{Geophagy in Malawi}

In Malawi soils are eaten by both rural and urban pregnant women of Malawian and Indian origin ${ }^{5}$. The rural women get the soils from selected sites, usually within walking distance of the home. Traders make rural soils available for geophagy in urban settings at local produce markets. Indian women mostly buy imported Indian soils which are sold in shops.

Some of the women in the lower Shire valley eat the vertisol type of soil (Makande, which is blackish in colour, mainly consisting of the $2: 1$ clay mineral montmorillonite, with higher $\mathrm{pH}$ and cation exchange capacity (hence more nutrients and possibly more toxic substances). But most Malawian women eat the oxisol and alfisol types of soil (Katondo, which are reddish in colour, mainly consisting of $1: 1$ clay mineral kaolinite with lower $\mathrm{pH}$ and cation exchange (apacity) ${ }^{19}$.

There is plenty of data on $\mathrm{Ca}, \mathrm{Mg}, \mathrm{Zn}, \mathrm{Cu}, \mathrm{Fe}$, and $\mathrm{K}$ in top soils $(015 \mathrm{~cm})$ and sub soils $(1530 \mathrm{~cm})$ which is available at main governmental agricultural research stations ${ }^{19}$. But the data is for agricultural soils. We are not aware of data on deep soils $(6090 \mathrm{~cm})$ which are consumed by pregnant women. This study attempted to assess the quality of the deep soils that are eaten by pregnant women in the city of Blantyre.

\section{Materials and Methods}

\section{Questionnaire}

Simple questionnaires on soil consumption were distributed to women at Limbe market in Blantyre city. We administered the questionnaire in person. The questionnaires were in
English language. We translated the questions into Chichewa for those who did not understand English and filled the questionnaire for them. 100 questionnaires were distributed, ninety to pregnant women who ate soils (who were identified as they were buying the soils for their consumption) and 10 to women who did not eat soils (who were randomly selected at the market).

The questionnaire was designed to bring out information on reasons for eating soils, period and frequency of eating soils, amounts of soils eaten (the women were requested to show the amounts of soils they ate daily and we weighed the estimated amounts of soils on a scale) and any known side effects of the soils eaten. An example of the questionnaire is shown in Appendix 1.

\section{Soil Sampling and Sample Preparation}

Soil traders at Limbe market led the authors of this paper to the sites; Ndirande, Mpingwe and Soche hills around Blantyre city, where they collect the soils that they sell at the market. Soil samples $(0.5 \mathrm{~kg})$ were collected from each site, using a soil drill, from soil pits used by women. The soil samples were collected at depths of about $70 \mathrm{~cm}$, the average depth from which the edible soils are taken. The soil samples were collected three times from each site.

The soil traders mentioned that pregnant Indian women buy their soils from a particular shop in Limbe. The shop owner imported the soil from India. We were not aware of any data for the Indian soil. So we bought soil samples, also three times, from this shop to analyse the soil and compare its quality with the quality of the Malawian soils.

The soil samples were collected in clear plastic bags and labelled with waterproof ink.

The local samples from Ndirande, Mpingwe and Soche were oxisols, reddish in colour, and were identified in the laboratory as 1,2 and 4, respectively. The soil sample from India was whitish in colour and was identified in the laboratory as sample 3 .

The samples were air dried and crushed using a porcelain mortar and pestle. Plant materials and small rock particles were removed. The soils were then ground, using a mortar and pestle, and passed through a two millimetre $(2 \mathrm{~mm})$ sieve. The sieved soils were stored in plastic bags while waiting analysis.

\section{Soil Analysis}

The soil samples were analysed using standard methods of analysis as described below.

a) Iron ( $\mathrm{Fe})$, calcium $(\mathrm{Ca})$, zinc $(\mathrm{Zn})$, lead $(\mathrm{Pb})$ and magnesium $(\mathrm{Mg})$.

The method below ${ }^{20}$ was chosen because it gives an estimate of the total amount of the element in the soil, hence the amount that would be released in the body.

\section{a. 1 Soil digestion}

1g. soil samples were mixed with $12 \mathrm{ml}$ concentrated Sulphuric acid, $5 \mathrm{mls}$ concentrated nitric acid and $1.5 \mathrm{mls}$ distilled water in a $100 \mathrm{ml}$ Kjeldahl flask which contained a few anti-bumping granules. The flasks were inserted into a heating unit and were heated to boiling point until a clear solution was obtained. More concentrated nitric acid was added drop by drop to samples that remained coloured after boiling until clear solutions were obtained. The samples were cooled, filtered into $50 \mathrm{ml}$ volumetric flasks and topped up to 
the mark with distilled water.

The standard solutions were prepared by the addition of known amounts of $\mathrm{Fe}, \mathrm{Ca}, \mathrm{Zn}, \mathrm{Pb}$ and $\mathrm{Mg}$ into $50 \mathrm{ml}$ volumetric flasks with $12 \mathrm{ml}$ concentrated sulphuric acid, 5 $\mathrm{ml}$ concentrated nitric acid and $1.5 \mathrm{ml}$ distilled water and topped up to the mark with distilled water.

\section{A. Detection of Fe, Ca, Zn, Pb and Mg}

$\mathrm{Fe}, \mathrm{Ca}, \mathrm{Zn}, \mathrm{Pb}$ and $\mathrm{Mg}$ in the said abstracts were detected using a GBC 932/933 Atomic Absorption Spectrophotometer, manufactured by GBC Scientific Equipment, PTY Limited.

\section{b.Determination of soil $\mathrm{pH}$}

Ten grammes $(10 \mathrm{~g})$ of soil sample were mixed with $25 \mathrm{ml}$ distilled water in a $50 \mathrm{ml}$ tube to determine soil $\mathrm{pH}$, The mixture was shaken (using a mechanical shaker) for 10 minutes then allowed to settle for 30 minutes. The $\mathrm{pH}$ of the sample was read on a $\mathrm{pH}$ meter ${ }^{20,21}$.

\section{c.Determination of bacillus}

$10 \mathrm{~g}$ of soil sample were mixed with $90 \mathrm{ml}$ of distilled water in a $150 \mathrm{ml}$ beaker to determine bacillus. The supernatant liquid was decanted into a flask and heated to 800C, with the mouth of the flask closed with cotton wool. $1 \mathrm{ml}$ from the flask was mixed with $9 \mathrm{ml}$ of distilled water in a test tube. 1 $\mathrm{ml}$ from the test tube was spread onto a sterilized Petri dish with nutrient agar broth $(8.4 \mathrm{~g}$ of nutrient agar thoroughly mixed with $300 \mathrm{ml}$ distilled water, autoclaved at $12 \mathrm{VC}$ for 15 minutes and cooled to $450 \mathrm{C}^{22}$.

The Petri dish was heated in boiling water in a steam bath for 10 minutes in order to kill all the vegetative cells that might have been introduced during culturing. The dishes were then incubated at $370 \mathrm{C}$ for 24 hours in an incubator. Then bacterial colonies were counted.

\section{d. Determination of clostridium}

The soil samples were treated and spread on sterilized Petri dishes with nutrient agar broth as described for bacillus. However, the Petri dishes were introduced into the oxygen extraction furnace (in order to remove all the oxygen in the Petri dishes) before incubation at 370C for 24 hours $^{22}$. After incubation the colonies were counted.

\section{Replication}

Each of the analyses was replicated three times. Each mean in Tables $I$ and 2 is an average of nine values.

\section{Results}

\section{a. Questionnaire Findings}

Eighty percent (72 out of 90) of the women interviewed believed that the soils they eat improve their blood by providing iron. Some believed the soils help to control nausea and vomiting. Others believed the soils are good for their general health. Yet others believed the soils produce good flavour that makes them feel comfortable. The frequency of consuming soils varied considerably. Some women indicated that they ate soils twice a day, in the morning and in the afternoon. Some indicated they ate soils before or after main meals (breakfast, lunch and supper). Yet others indicated they ate soils throughout the day, anytime they have a craving or felt like doing so.

The quantities of soils consumed varied considerably, ranging from 10 to $90 \mathrm{~g} /$ day. On average, the pregnant women consumed $50 \mathrm{~g}$ of soil per day.

Ninety-nine percent of the respondents indicated they ate air dried soils. Only 1\% ate baked soils. The women believed the soils have no harmful effects. Women who did not eat soils believed the soils have harmful effects. They speculated that the soils may not be completely digestible in the stomach, hence may cause acute and recurrent abdominal pains. One respondent indicated that her mother, who liked to eat soils, frequently complained of abdominal pains, eventually had appendicitis and her appendix was removed by doctors at Queen Elizabeth Central Hospital; but her mother refused to link her illness to the soils she ate. Other women believed soils caused diarrhoea because of the unhygienic way in which they are collected, handled and stored.

\section{b) Soil quality}

Analytical data for soils is shown in Table 1: Iron, Calcium, Zinc, Magnesium, Lead, pH, Bacillus and Clostridium levels in the soils

\begin{tabular}{|l|l|l|l|ll|l|}
\hline \multirow{2}{*}{ Parameter } & \multicolumn{5}{|l|}{ Soil Sources } \\
\cline { 2 - 7 } & Ndirande & 2. Mpingwe & 3. India & 4 . Soche & Mean & Standard deviation \\
Calcium, mg/g & 0.412 & 0.450 & 0.388 & 0.525 & 0.444 & \pm 0.06 \\
Zinc, mg/g & 0.042 & 0.050 & 0.082 & 0.050 & 0.056 & \pm 0.017 \\
\hline $\begin{array}{l}\text { Magnesium, } \\
\text { mg/g }\end{array}$ & 0.00035 & 0.019 & 0.026 & 0.021 & 0.022 & \pm 0.003 \\
Lead, mg/g & 0.05 & 0.05 & 0.07 & 0.06 & 0.058 & \pm 0.01 \\
pH & 5.51 & 5.58 & 7.05 & 5.53 & 5.70 & \pm 0.70 \\
\hline $\begin{array}{l}\text { Bacillus } \\
\text { (Colonies/gram) }\end{array}$ & 13475 & 7875 & 4900 & 11950 & 9500 & \pm 3978 \\
\hline $\begin{array}{l}\text { Clostridium } \\
\text { (Colonies/gram) }\end{array}$ & 9050 & 6650 & 5050 & 6450 & 6800 & \pm 1660 \\
\hline
\end{tabular}

There was association between iron levels and colour of the soils, the more reddish the soil the higher the iron content. Blantyre soils had more iron than the Indian soil.

The soil from India had the highest calcium content, with highest $\mathrm{pH}$ and a whitish colour.

All the soils contained lead; with the soil from India having the highest concentration of $0.07 \mathrm{mg} / \mathrm{g}$.

The $\mathrm{pH}$ values of the soils ranged from 5.51 to 7.05 , with a mean of $5.70 \pm 0.70$. The soils from Blantyre were acidic, with $\mathrm{pH}$ values ranging from 5.51 to 5.58. The soil from India had a neutral $\mathrm{pH}$ (7.05). As expected, soils with lower $\mathrm{pH}$ had more iron but less calcium than soils with higher $\mathrm{pH}$. Lead and zinc generally increased with increasing $\mathrm{pH}$.

All the soils had microbial contamination as evidenced by the presence of spores of bacillus and clostridium. The Indian soil had lower contamination than the Blantyre soils.

\section{Discussion}

Based on average consumption of $50 \mathrm{~g}$ of soil per day these women consume 19.4 to $26.25 \mathrm{mg}$ with a mean of $22.2 \mathrm{mg}$ of iron per day. Iron levels in the soils are close to the WHO recommended daily intake of $30 \mathrm{mg} \mathrm{Fe} /$ day for pregnant women. The 'edible' soils can supply $74 \%$ of the WHO recommended minimum daily intake of iron.

The WHO recommended value of $30 \mathrm{mg} \mathrm{Fe} /$ day is for the ferrous form of iron. Iron in the body is absorbed in the ferrous $(\mathrm{Fe} 2+)$ form ${ }^{23}$. Iron tablets recommended for pregnant women contain the ferrous form of iron as ferrous sulphate (FeS04).

The iron in the soils demands further investigations. The soils, throughout Malawi, should be characterized to assess the form of iron which is mostly present and to check if the soils contain enough iron.

Daily average consumption of $\mathrm{Ca}, \mathrm{Zn}$ and $\mathrm{Mg}$ per $50 \mathrm{~g}$ 
soil would be $2.8,1.1$ and $0.019 \mathrm{mg}$, respectively. The recommended WHO minimum daily intake values for $\mathrm{Ca}, \mathrm{Zn}$ and $\mathrm{Mg}$ are 1500, 15 and $320 \mathrm{mg}$, respectively, for pregnant women. The soils may provide approximately 0.2 , 7 and 0.006 percent of the recommended minimum values for $\mathrm{Ca}, \mathrm{Zn}$ and $\mathrm{Mg}$, respectively. The soils may contribute to dietary $\mathrm{Ca}$ and $\mathrm{Zn}$ but not Magnesium.

The fact that the soils contain lead is worrisome. Lead is a toxic element ${ }^{24}$ and it accumulates in the body ${ }^{25}$. Lead has chronic effects and people consuming the soils may, therefore, not be able to relate soil consumption with effects of lead. High lead levels in, 'edible' soils, may contribute to high lead levels in blood. High lead levels in blood result in a decrease in intelligence quotient (IQ) of children. Lead consumed by pregnant women may possibly affect the IQ of the foetus. There is need for further research to study the health effects of the lead in the soils.

The soils eaten by the pregnant women are usually dry. Vegetative cells of bacteria die in dry conditions, but spores can exist in dry soils. Bacillus cereus and Clostridium perfringes are spore forming bacteria. Their spores can survive in soils up to $80^{\circ} \mathrm{C}$ and for many years ${ }^{25}$. When the spores enter the body, they germinate in the stomach and intestines. A person can start feeling abdominal pains between 10 to 12 hours after ingestion of the bacillus spores ${ }^{12}$. For Clostridium perfringes symptoms of abdominal pain or diarrhoea can manifest 8 to 24 hours after their ingestion ${ }^{12}$.

Ninety- nine percent $(99 \%)$ of the pregnant women interviewed indicated they eat air dry soils. Some of them indicated suffering from abdominal pains during pregnancy, but they could not link the abdominal pains to the soils they ate. When women eat air dry soils they expose themselves to bacterial spores.

Comparison of the $\mathrm{pH}$ and the concentrations of the elements in the soils showed some significant differences (LSD0.05) between the Blantyre soils and the soil from India. Generally the quality of the three Blantyre soils was similar but different from that of India. The India soil had higher $\mathrm{Ca}, \mathrm{Zn}, \mathrm{Mg}, \mathrm{Pb}$ and, $\mathrm{pH}$ but lower $\mathrm{Fe}$ content than Blantyre soils. The $\mathrm{pH}$, iron, calcium, magnesium, zinc, and lead content of the India soil differed from that of at least one of the Blantyre soils. The only noticeable difference between the Blantyre soils was for iron, where the Soche soil had higher iron than the Ndirande soil.

The variations in the quality of the soils could be due to differences in the composition of the rocks that weathered to form the soils. For example rocks with haematite and pyrite would produce iron rich soils, rocks with gypsum, limestone and dolomite would produce calcium rich soils, rocks with zincblende would produce zinc rich soils and rocks with magnesite dolomite would produce magnesium rich soils. The topography and climatology conditions also affect element concentrations in soils.

The study had several limitations. Firstly, the only other foreign 'edible soil' we could find was from India. The Malawi soils were, therefore, compared to the Indian soil only. The shop owner could not specify the exact source in India of the imported soil.

Secondly, the analytical method tested for total iron, which may have been $\mathrm{Fe} 2+$ or $\mathrm{F} 3+$. Further studies should be done to check Fe2+ in the 'edible' soils.

Thirdly, the study had sampling limitations. Pregnant women who were interviewed were identified as they were buying the 'edible' soils at Limbe market. It would be interesting to interview a representative sample of all pregnant women in Malawi to know the proportion of pregnant women who consume soils.

Fourthly, Soils vary in their composition from one area to another and from one depth to another within a soil profile. The quality of soils tested in this study may not be representative for Blantyre or Malawi. There is need for further studies to assess the nutritive potential of 'edible' soils (top and sub) from other areas in Malawi and produce a geological map of the distribution of soils and their elemental composition.

Fifthly, many potential harmful (known and unknown) substances, such as helminth eggs, which may be present in the soils were not assessed.

\section{Conclusion and Recommendations}

The results indicate that the 'edible' soils have nutritive potential, especially for iron. Iron deficiency is a major problem amongst pregnant women in Malawi and the soils potentially provide a valuable source of iron. The 'edible' soils can also significantly contribute to dietary calcium and zinc. However, the soils contain lead and spores of bacteria which may have harmful health effects.

Further studies should be conducted to assess the nutritive potential of 'edible' soils from other areas in Malawi.

Further multidisciplinary research should be conducted to assess other potential harmful substances that may be present in soils, examine the digestibility of the 'edible' soils and assess health effects of lead and bacterial spores.

\section{Acknowledgements}

The authors wish to thank M. Kamwachale, F. Kunkundi and A. Maliro, all from Polytechnic and J. Kamanula of Chancellor College for their skilful laboratory assistance in preparation and analysis of soil samples. Discussions and contributions from Dr Jere, of the Gynaecology Department at Queen Elizabeth Central Hospital, have been highly beneficial. The editorial work by Dr Adamson Muula is also highly appreciated.

The authors also wish to thank the management of Polytechnic for funding the research activities

\section{References}

1. ATSDR (Agency for Toxic Substances and Diseases Registry). Summary report for the ATSDR Soil Pica Workshop, Atlanta, Georgia; 2000. Available from: URL: http://www.astdr.cdc.gov/NEVS/soil pica. html

2.Absolute Astronomy. 2011 Available from http://www. absoluteagronomy.com/Encyclopedia/Geophagy

3.Johns T. With bitter herbs they shall eat it: chemical ecology and the origins of human diet and medicine. 1990. Tucson (AZ): University of Arizona Press.

4.Baghurst PA, McMichael AJ, Wigg NR, Vimpani GV, Robertson EF, Roberts RJ, Tong Shi Lu. Environmental exposure to lead and children's intelligence at the age of seven years. N. Eng. J. Med. 1992;327: 1279 84.

4.Callahan GN. Emerg. Infec. Dis. 2003;9(8): 1016 - 1021. Available from http://www.cdc.gov/ ncidod/EID/vol 9 no 8/03 0033.htm

5.Callahan KL. Pica, Geophagy and Rock Art: Ingestion of rock powder and clay by humans and its implications for the production of some rock art on a global basis. A paper read at the Philadelphia SAA 
conference in April 8, 2000. Available from: http://www.oocities.org/ athens/acropolis/5579/pica.html

6.Granny DR. Iron deficiency symptoms. Available at http://www. drgranny.com/fitness/iron-deficiency-symptoms/ 2011.

7.Wiley AS, Solomon HK. Geophagy in pregnancy: a test of a hypothesis, Current Anthropology 1998;39:532 545.

8.Saka AR. Personal Commutation. Saka was Soils commodity team leader at Chitedze Agricultural Research Station, Lilongwe, Malawi. January 2006

9. Mowat AM. Anatomical basis of tolerance and immunity to intestinal antigens. Nat. Rev. Immunol. 2003;3: $331-341$

10. Noguera Obenza M; Ochoa JJ, Gomez HF, Guerrere ML, Herrera Insua, In Morrow, A.L; et. al. Human milk secretory antibodies against attaching and effacing Eschericia Coli antigens. Emerg. Infect. Dis. 2002;9:545 555 .

11Fitzpatrick EA. An introduction to soil science. 3rd ed. Hong Kong: Oliver and Boyd Publishers; 1991.

12. Cruickshank R. Medical microbiology. 11th ed. Edinburgh: Churchill Livingstone Publishers; 1973.

13.CDCP (Center for Disease Control and Prevention). Racoon roundworm encephalitis Chicago, Illinois, and Los Angeles, CA, 2000. MMWR Morb Mortal Weekly Report 2002;50:1153 1155.

14. Laufer M. Toxocariasis. 2002 Available from URL http://www. emediciiie.com/ped/topic 2270.htm

15.Geissler PW, Mwaniki D, Thiong F, Friis H. Geophagy is a risk factor for geohelminth infections: a longitudinal study of Kenyan primary school children. Trans R Soc Trop Med Hyg. 1998;92:7 11.
16.Ozumba UC, Ozumba N. Patterns of helminth infection in the human gut at the University of Nigeria Teaching Hospital, Enugu, Nigeria. J. of health science 2002;48:263 268 .

17.Kawai K, Saathoff E, Antelman G, Msamanga G and Fawzi WW. Am. J. Trop Med Hyg 2009;80(1): 36 - 43.

18.Saka AR. Personal Commutation. Saka was Soils commodity team leader at Chitedze Agricultural Research Station, Lilongwe, Malawi. January 2006

19.Rayment GE and Lyons DJ. Soil chemical methods - Australasia. CSIRO Publishing. 2010

20.Soils Team Leader. Laboratory manual for soil, plant and miscellaneous analysis, Chitedze agricultural research station: Lilongwe 2010 .

21.Collins CH, Lyne, P.M. 5th ed. Microbiological Methods. LondonBoston: Butterworths; 1984.

22.Jurac Corporation. 2006. Iron. http://www.jctonic.com/include/ minerals/iron.htm

23. Mott J. Lead poisoning and essential care of children and families. Britain; 1989.

24.Farley D. Dangers of lead still linger. U. S. Food and Drug Administration. FDA consumer. 1998. Available from http://www. cfsan.fda.gov/ dms/fdalead.html

25. Alexander M. Introduction to soil microbiology. 6th Edition. Wiley publications. 